DOI: $10.15290 / \mathrm{bsl} .2021 .19 .05$

Creative Commons License: CC BY-SA 4.0

https://creativecommons.org/licenses/by-sa/4.0/deed.en

\title{
Mikołaj Paczkowski
}

Wydział Filologii Polskiej i Klasycznej

Uniwersytet im. Adama Mickiewicza w Poznaniu

e-mail: paczkowski.mikolaj@gmail.com

ORCID: 0000-0002-0723-7786

\section{„Stworzyć tu naprawdę śliczną a bogatą kolonię polską". Polskie międzywojenne opisywanie Peru*}

W polskim podróżopisarstwie dwudziestolecia międzywojennego Peru jako cel wyprawy pojawiło się dopiero na początku lat 30. Wzmożonego zainteresowania tym krajem trudno nie łączyć $\mathrm{z}$ obecną $\mathrm{w}$ ówczesnym dyskursie publicznym ideą zakładania polskich kolonii osadniczych nad rzeką Ukajali, którą w tym okresie zaczęto wcielać w życie. Pomiędzy rokiem 1928 a 1935 ukazało się dziewięć rodzimych publikacji poświęconych Peru. Były to (wymieniając w kolejności chronologicznej): Michała Pankiewicza Ustrój społeczny Montanji peruwianskiej a praktyczne wskazania dla polskiego osadnictwa (1929), Kazimierza Warchałowskiego Peru. Warunki gospodarcze Montanji Peruwiańskiej (1930), Mieczysława Lepeckiego Opis polskich terenów kolonizacyjnych w Peru (1930) oraz Na Amazonce i we wschodnim Peru (1931), Adama Jarzyny Peru. Widoki dla osadnictwa rolnego na terenach polskich koncesyj (1931), Tomasza Oxińskiego Peru (1932), Michała Gieysztora Peru (1933), Marii Bochdan-Niedenthal Ucayali. Raj czy piekło nad Amazonka (1935) oraz Arkadego Fiedlera Ryby śpiewaja w Ukajali (1935). Część to relacje z podróży do Ameryki Południowej, pozostałe stanowią opracowania popularnonaukowe, przybliżające wiadomości na temat historii, polityki, ekonomii oraz warun-

\footnotetext{
* Tekst powstał w wyniku realizacji projektu badawczego Nowoczesność i egzotyka. Podróżopisarstwo polskie $w$ dwudziestoleciu międzywojennym nr 2020/37/N/HS2/01700 finansowanego ze środków Narodowego Centrum Nauki.
} 
ków przyrodniczych kraju. Warto przyjrzeć się, w jaki sposób polscy autorzy prezentowali Peru oraz co wpływało na ich sposób pisania o odwiedzanym miejscu.

\section{„Peruwiańska gorączka”}

Idea polskiego osadnictwa w Peru narodziła się w roku 1924 i była wynikiem sytuacji społeczno-politycznej panującej ówcześnie w obu państwach. Władze w Limie od połowy XIX wieku prowadziły politykę imigracyjną, która miała ułatwić zasiedlenie wschodnich obszarów kraju. W Polsce z kolei trwała dyskusja dotycząca przeludnienia (szczególnie na wsi), a wychodźstwo mogło okazać się idealnym rozwiązaniem problemu "ludzi zbędnych"1. Koncepcja zakładania polskich kolonii ${ }^{2}$ w Montanii peruwiańskiej została więc początkowo przyjęta $z$ entuzjazmem.

Za ojca "gorączki peruwiańskiej" w Polsce, z całą pewnością, uznawać trzeba Kazimierza Warchałowskiego - działacza emigracyjnego i publicystę, wcześniej pracującego wśród Polonii brazylijskiej. Warchałowski już w 1926 r. w czasie własnych odczytów oraz na łamach prasy zaczął propagować ideę polskiego osadnictwa $\mathrm{w}$ tym kraju. Argumentował, że Peru jest ostatnim miejscem na ziemi, w którym pozostało na tyle dużo wolnego terytorium, aby stworzyć znaczącą kolonię polską dla sporej rzeszy emigrantów. Idealnym osadnikiem miał być - w oczach propagatora - bezrolny chłop polski ${ }^{3}$. Choć idea ta spotkała się z krytyką innych działaczy emigracyjnych oraz wątpliwościami instytucji publicznych, podkreślających nikłe szanse na realizację pomysłu, trafiła na podatny grunt wśród potencjalnych kolonistów. W 1927 r. konsulat peruwiański w Polsce informował w specjalnym komunikacie prasowym o setkach listów, przychodzących od ludzi zainteresowanych wyjazdem do Ameryki Południowej. Jednocześnie urząd podkreślał, że ani paszportu, ani ziemi załatwić w żaden sposób nie może ${ }^{4}$.

1 K. Kurowski, Relacje polsko-peruwiańskie w latach 1923-1945. Działalność Polaków w Peru, w: Polacy w dziejach Peru, red. S. Rakowicz, Torun 2019, s. 144-145.

${ }^{2}$ W międzywojennym piśmiennictwie wyrażenie „kolonia” pojawia się zarówno jako określenie zamorskiego terytorium danego państwa, jak i jako osada zamieszkiwana przez spójną etnicznie czy narodowościowo grupę ludzi.

3 J. Mazurek, Piórem i czynem. Kazimierz Warchałowski (1872-1943) - pionier osadnictwa polskiego w Brazylii i Peru, Warszawa 2013, s. 215.

4 Tamże, s. 216. 
Warchałowskiego nie zrażały głosy krytyki. Wraz z grupą małopolskich ziemian założył Polsko-Amerykański Syndykat Emigracyjny, który miał zająć się pozyskaniem od rządu peruwiańskiego ziemi pod przyszłe polskie kolonie. Bardzo szybko wszedł on jednak w konflikt z pozostałymi udziałowcami, dlatego ostatecznie negocjacje z władzami Peru prowadzili osobno Syndykat i Warchałowski. Obie strony uzyskały koncesję na prowadzenie działalności osadniczej na terenie Montanii, po dwu stronach rzeki Ukajali. Syndykatowi przypadł obszar o łącznej powierzchni miliona hektarów, Warchałowski musiał zadowolić się terytorium 350 tys. hektarów. Głównym warunkiem otrzymania ziemi na własność była konieczność sprowadzenia do Peru określonej liczby rodzin osadniczych. Kazimierz Warchałowski zobowiązał się do ulokowania tysiąca rodzin w przeciągu czterech lat od rozpoczęcia działalności ${ }^{5}$.

Problemy pojawiły się wraz z koniecznością pozyskania środków finansowych na pokrycie kosztów wysłania chętnych do Ameryki. Bank Gospodarstwa Krajowego, w którym Warchałowski zabiegał o wsparcie, postawił warunek powołania specjalnej ekspedycji, mającej ocenić szanse powodzenia projektu. Do Peru wyjechała więc grupa składająca się przede wszystkim z działaczy emigracyjnych, zabrakło w niej natomiast ekspertów, którzy mogliby $\mathrm{w}$ profesjonalny sposób zbadać tak istotne $\mathrm{z}$ punktu widzenia emigracji kwestie, jak klimat, wartość gleb czy zagrożenie chorobami tropikalnymi. $Z$ tego powodu organizację wyprawy krytykowano w środowisku związanym z działalnością osadniczą. Opinia przygotowana przez członków ekspedycji była zasadniczo pozytywna, nie zabrakło w niej jednak wątpliwości ${ }^{6}$.

\section{Kolonialna propaganda}

Z osób pracujących $\mathrm{w}$ komisji trzy napisały książki poświęcone polskiemu osadnictwu w Peru. Mowa tu o Michale Pankiewiczu, Mieczysławie Lepeckim oraz samym Kazimierzu Warchałowskim. Swoją wyprawę opisał także Michał Gieysztor, kierujący na terenie Montanii pracami przygotowawczymi do osadnictwa ze strony Polsko-Amerykańskiego Syndykatu Kolo-

\footnotetext{
5 M. Jarnecki, Peruwiańska porażka i próba jej naprawy. Wokót polskich międzywojennych koncepcji emigracyjnych i kolonialnych, „Sprawy Narodowościowe. Seria Nowa” 2014, nr 44, s. 106-107.

6 M. Kania, Żyć można w Montanji całe lata - o kolonizacji polskiej w Peru, w: Pani Anna w Kanadzie: księga pamiątkowa dedykowana Pani Profesor Annie Reczyńskiej, red. M. Gabryś, M. Paluszkiewicz-Misiaczek, Kraków 2016, s. 23-25.
} 
nizacyjnego. Sposób prezentowania Peru jest zbieżny we wszystkich tych publikacjach. Autorzy eksponowali przede wszystkim kwestie mogące mieć istotne znaczenie dla potencjalnego wychodźcy. Podkreślali uwarunkowania przyrodnicze, które, $\mathrm{w}$ ich ocenie, sprzyjały emigracji, takie jak umiarkowany klimat, żyzność gleb czy położenie w obszarze niepodlegającym zalewaniu w porze deszczowej. Kazimierz Warchałowski tak pisał o możliwościach uprawy ziemi nad Ucayali:

Rolnictwo nie wymaga tu prawie zupełnie nakładu[,] na razie zbędna jest orka, bronowanie, itp., niepotrzebne więc są pługi, brony, siewniki, itp., a także konie i woły do pociągu; bogata gleba nie wymaga nawożenia. Uprawa polega na ścięciu lasu i spaleniu go ${ }^{7}$.

W podobnym tonie autor przedstawiał wszystkie aspekty życia w Peru. Podkreślał brak zagrożenia ze strony dzikich zwierząt czy chorób zakaźnych, ogromną ilość zasobów naturalnych oraz pokojowe usposobienie rdzennej ludności. Broszura zawiera także liczne wiadomości praktyczne, takie jak aktualne zestawienia cen, opis sytuacji na rynku pracy, sposób adresowania korespondencji kierowanej do polskiego konsulatu honorowego w Limie. Jak zaznacza Jerzy Mazurek, Warchałowski w swoich publikacjach czy wystąpieniach „nie wykazał się obiektywizmem. Wyolbrzymiał bowiem pozytywne strony terenów koncesyjnych oraz pomijał milczeniem sprawy niewygodne" 8 . Podobną strategię w swojej książce Peru zastosował Michał Gieysztor, mimo że ukazała się ona już w 1933 r., a autor, który spędził w Montanii dwa lata, był świadkiem porażki projektu kolonialnego. Publikacja ta również zawiera liczne informacje mające skłonić potencjalnych emigrantów do osiedlenia się w Ameryce Południowej. Oprócz pracy na roli, koloniści mieliby bogacić się dzięki sprzedaży rzadkich odmian drewna pozyskiwanych przy wycinaniu puszczy, takich jak cedr, mahoń, palisander czy słoniorośl (popularna ówcześnie roślina, wykorzystywana do produkcji imitacji kości słoniowej). Gieysztor informował nawet o aktualnej cenie „za młodą dziewczynę lub dziecko" (sic!) i choć podkreślał, że oficjalnie handel ludźmi jest zakazany, dodawał jednocześnie, iż na terenach, „gdzie w ogóle brak wszelkiej władzy"9 prawo to nie jest respektowane. Warto zwrócić uwagę na sposób, $\mathrm{w}$ jaki opisuje on swoje pierwsze wrażenia z pobytu na ziemiach przyznanych Syndykatowi Kolonizacyjnemu:

\footnotetext{
7 K. Warchałowski, Peru. Warunki gospodarcze Montanji Peruwiańskiej, Warszawa 1930, s. 22.

8 J. Mazurek, Piórem i czynem, s. 234.

9 M. Gieysztor, Peru, Warszawa 1933, s. 58.
} 
Trzydniowa podróż po Urubambie była bardzo miła, bo nie tylko czułem się jak u siebie w domu, jechałem bowiem przez tereny należące do koncesji Syndykatu Kolonizacyjnego, ale i śliczne widoki, urwiste brzegi, moc wszelkiego zwierza i ptactwa, a głównie znaczne obniżenie temperatury, chłodna woda rzeki i zupełny brak komarów przyczyniły się do tego, że czułem się tu doskonale ${ }^{10}$.

Oprócz wskazania na obfitość południowoamerykańskiej przyrody w owoce i zwierzynę, autor podkreśla indywidualne, jednoznacznie pozytywne odczucia, oparte o własne przeżycia i doświadczenia. Istotne jest tutaj także wrażenie „bycia u siebie w domu”, które oswaja przestrzeń, mającą w powszechnym wyobrażaniu Europejczyków charakter egzotyczny. Gieysztor odnosi się wreszcie do najpopularniejszych obaw związanych z wyobrażeniami Ameryki Południowej: nieustannych upałów oraz chorób przenoszonych przez owady, jednoznacznie stwierdzając, że nie są one realnym zagrożeniem.

Nieco bardziej wyważone sądy o realiach panujących w Peru prezentował redaktor Wychodźcy Michał Pankiewicz. Jednak, choć wskazywał on na mankamenty dotyczące życia nad Ukajali, ostatecznie również w jego publikacji Ustrój społeczny Montanji peruwiańskiej a praktyczne wskazania dla polskiego osadnictwa ${ }^{11}$ przeważała opinia o warunkach sprzyjających akcji emigracyjnej. Sprzeczności w tekście dostrzegała redakcja „Dziennika Bydgoskiego”, która przez niemal cały styczeń 1932 roku publikowała na łamach czasopisma artykuły pod wspólnym tytułem Tragedia emigrantów polskich. W części poświęconej analizie książeczki Pankiewicza stwierdzano:

Więc godzi się zapytać, na co zda się owa „wielka urodzajność gleby” w opisie na str. 4? Na str. 13 tej broszury autor mówi: „W tych warunkach trudno jest mówić o rolnictwie w Montanji". - I w tem jednem p. Pankiewicz jest szczery, w tem zgodzić się z nim trzeba. Dlaczego zatem rozpisuje się „bujdy" o urodzajności gleby, dlaczego się zwodzi społeczeństwo i ludzi naiwnych, dlaczego i dla kogo tyle huku dokoła kolonizacji Peru? Na co to wszystko? ${ }^{12}$

Ambiwalentne opinie, podsumowane jednak pozytywną rekomendacją dotyczącą osadnictwa w Montanii, znalazły się wreszcie w dwu książkach napisanych przez Mieczysława Bohdana Lepeckiego. Pierwsza z nich, Opis

\footnotetext{
10 Tamże, s. 29-30.

11 M. Pankiewicz, Ustrój społeczny Montanji peruwiańskiej a praktyczne wskazania dla polskiego osadnictwa, Warszawa 1929.

12 Tragedia emigrantów polskich VII, „Dziennik Bydgoski” 1932, nr 19, s. 4.
} 
polskich terenów kolonialnych w Peru, to rozbudowany informator, prezentujący przebieg ekspedycji badawczej i protokół przedstawiający stanowisko komisji, a także zestawienie danych geograficznych o terenach pozyskanych przez polskich koncesjonariuszy. Autor zakończył swój wywód przekonaniem, że "kolonia ta rozwinie się w przyszłości znakomicie i zachęci władze limańskie do organizowania coraz to nowych ośrodków rolniczych"13, a wątpliwości wzbudzała w nim jedynie możliwość problemu z zaaklimatyzowaniem się na stałe $\mathrm{w}$ Ameryce Południowej osadników pochodzących z Europy centralnej.

Znacznie ciekawszą, z literaturoznawczego punktu widzenia, jest druga publikacja podróżnika Na Amazonce i we wschodnim Peru. Ze względu na przynależność gatunkową - to reportaż podróżniczy, czerpiący jednak z tradycji powieści przygodowej - Lepecki nie mógł pozwolić sobie na wyłącznie sielankowe opisywanie odwiedzanych miejsc. Podzielił więc wyprawę na dwa etapy, które przedstawił w odmienny sposób. Pierwsza część książki prezentuje przybycie do Ameryki Południowej oraz podróż w górę Amazonki. Ten odcinek ekspedycji nasycony jest niebezpiecznymi i zaskakującymi zdarzeniami, takimi jak pożar statku oraz przymusowe obozowanie w amazońskiej dżungli (autor sam porównuje się do Robinsona Crusoe), wyprawy myśliwskie czy spotkania z rdzennymi mieszkańcami, którzy mieli poznać smak ludzkiego mięsa. Wszystkie wydarzenia rozgrywają się w pierwotnej puszczy, egzotyzowanej w opisach, aby jeszcze bardziej podkreślić ryzykowny charakter wyprawy:

Przedzierając się z trudem przez roślinne zapory, posuwaliśmy się naprzód. Co chwila musieliśmy kłaść się na dnie łodzi, aby móc prześliznąć się pod potężnemi konarami, którym maczeta nie dałaby rady. Naokoło rozlegał się świergot drobniejszego ptactwa, przerywany od czasu do czasu cichym gwizdem olbrzymich jastrzębi, lub dziwacznemi głosami wielkich, nieznanych mi ptaszysk. Nad dżunglą przeciągały stada papug, wrzeszcząc i łopocząc skrzydłami. Ani jeden promień słońca nie był w stanie przedrzeć się przez sklepienie lian, gałęzi i liści. Tylko żaru rozpalonej kuli słonecznej nie potrafiły powstrzymać żadne zapory ${ }^{14}$.

Sposób prezentowania Peru ulega jednak zmianie wraz ze zbliżaniem się do terenów objętych polską koncesją. „Ucayali wydało mi się jakieś inne, mniej mroczne aniżeli Amazonka"15, informował swoich czytelników Lepecki, a następnie opisywał warunki naturalne panujące w Montanii. Warto

\footnotetext{
13 M.B. Lepecki, Opis polskich terenów kolonialnych w Peru, Warszawa 1930, s. 77.

14 M.B. Lepecki, Na Amazonce i we wschodnim Peru, Lwów-Warszawa 1931, s. 56.

15 Tamże, s. 78.
} 
zwrócić uwagę na fakt, że w książce tej autor pozwolił sobie na więcej krytycznych uwag dotyczących obszaru, na którym mieli osiedlić się koloniści. Podkreślał trudności ze znalezieniem dogodnego miejsca na utworzenie osady, które nie podlegałoby podtopieniom w okresie opadów, informował o braku drzew kauczukowych w regionie czy wreszcie sugerował, że koncepcja polskiego osadnictwa nie była entuzjastycznie widziana przez Europejczyków już żyjących na tym terytorium. Mimo wszystko Lepecki w żadnej ze swoich publikacji nie zakwestionował sensu wysyłania emigrantów w dorzecze Ukajali.

Do emigracji nie zachęcali jednak wyłącznie ludzie bezpośrednio zaangażowani w tworzenie polskiej osady. Propagandowy charakter miała także, wydana w 1932 roku, popularnonaukowa broszura przygotowana przez Konsula Honorowego Peru w Warszawie, Tomasza Oxińskiego. Stanowiła ona odpowiedź na „najfantastyczniejsze i najsprzeczniejsze wprost legendy kursują[ce] po Polsce o tym kraju"16. Część merytoryczna publikacji zawiera informacje o sytuacji społeczno-politycznej oraz warunkach przyrodniczych panujących w "kraju złota i słońca”, takie jak wzmianka o najzdrowszym klimacie czy opis niesłychanych bogactw naturalnych. We wstępie autor podkreślał, że Polska, która z obiektywnych przyczyn odegrała znikomą rolę w historii odkryć i eksploracji, jak najszybciej powinna wejść na międzynarodową arenę walki o nowe terytoria:

Mimo braku naturalnych terenów ekspansji, jakiemi są zazwyczaj własne kolonje i mimo bardzo słabego stanu dotychczasowego marynarki handlowej, Polska może i powinna zbliżyć się bezpośrednio z państwami i narodami, nie ograniczając się jedynie do naturalnych lub przypadkowych sąsiadów, tem bardziej, że wśród dalekich ma przyjaźniejszych niż wśród najbliższych ${ }^{17}$.

Publikacje przygotowywane przez ludzi związanych z koncepcją polskiego osadnictwa w Peru były więc, mimo często deklarowanego obiektywizmu (zwłaszcza w przypadku tekstów popularnonaukowych), jednoznacznie podporządkowane funkcji perswazyjnej. Miały one na celu skłonienie potencjalnych osadników do podjęcia decyzji o emigracji (co często leżało w interesie piszących) przez przekonanie ich o panującym nad Ukajali dobrobycie oraz rozwianie obaw wynikających z powszechnych ówcześnie wyobrażeń o Ameryce Południowej. W ocenie autorów, Peru, przy małych nakładach pracy, mogłoby stać się dla polskich osadników „prawdziwym

16 T. Oxiński, Peru, Warszawa-Poznań 1932, s. 7.

17 Tamże, s. 6-7. 
rajem”, jak pisał Michał Gieysztor, czy „zielonym rajem” - to słowa Mieczysława Lepeckiego, które w oczywisty sposób nawiązują do bardzo często pojawiającego się określenia "zielone piekło" (infierno verde).

\section{Narracje krytyczne}

Idea polskiego osadnictwa w Peru spotkała się z krytycznymi reakcjami jeszcze przed uzyskaniem przez Warchałowskiego i Syndykat oficjalnych koncesji. Sceptyczne opinie - pisane także przez ekspertów - publikowane były przede wszystkim na łamach prasy ${ }^{18}$. Kwestionowano w nich informacje, na które powoływały się osoby zachęcające do emigracji. Jednym z czołowych przeciwników wysyłania kolonistów nad Ukajali był Adam Jarzyna - lwowski sędzia i znawca problematyki emigracyjnej. W swojej publikacji Peru. Widoki dla osadnictwa rolnego na terenach polskich koncesyj odnosił się do książek propagatorów koncepcji wychodźczej i przedstawionej w nich sielankowej wizji życia w peruwiańskiej dżungli, stwierdzając:

Fachowe sprawozdania mało są czytane, natomiast propagandowe broszurki koncesjonariuszy, popularne odczyty docierają do szerszych kół. Mirażami stworzenia nowych polskich kolonij zdołali koncesjonariusze pozyskać szereg poważnych osobistości i zachęcić do wstąpienia do spółdzielni „Kolonja Polska”, której istnienie ułatwia Warchałowskiemu robienie interesów. Informacje zawarte $\mathrm{w}$ broszurach propagandowych są oczywiście tendencyjne, a niejednokrotnie wprost fałszywe ${ }^{19}$.

Jarzyna podważał także podstawowe przesłanki, na których opierano przekonanie o optymalnych dla osadnictwa warunkach panujących $\mathrm{w}$ tej części Peru. Pisał: „niewiele znamy terenów emigracyjnych, gdzie białemu osadnikowi groziłoby tyle niebezpieczeństw ze strony klimatu, szkodliwych zwierząt i chorób, powodujących konieczność nieustannej opieki lekarskiej, co w Montanji" ${ }^{20}$. Wreszcie, autor stwierdzał, że nieprzemyślane działania inicjatorów "gorączki peruwiańskiej" mogą negatywnie wpływać na wszystkie kolejne projekty wychodźcze, utrudniając pozyskanie przychylności władz oraz przekonanie potencjalnych osadników do wyjazdu.

\footnotetext{
18 J. Mazurek, Piórem i czynem, s. 236-238.

19 A. Jarzyna, Peru. Widoki dla osadnictwa rolnego na terenach polskich koncesyj, Lwów-Warszawa 1931, s. 25.

20 Tamże, s. 12.
} 
Ambitny projekt polskiego osadnictwa w Peru zakończył się fiaskiem oraz kompromitacją jego organizatorów. Jako przyczyny porażki wskazywano zarówno czynniki zewnętrzne, na przykład rozpoczynający się właśnie Wielki Kryzys, jak i błędy popełnione przez osoby koordynujące akcję: chaos, brak przemyślanej koncepcji, zły dobór osadników, słabą znajomość peruwiańskich realiów ${ }^{21}$. Winą obarczano także personalnie Kazimierza Warchałowskiego. Ten odpierał zarzuty, atakując przy tym osadników, którzy w jego opinii „złożyli egzamin niedołęstwa i złej woli" 22. Łącznie do Peru trafiło około 200 polskich emigrantów, wśród których była również Maria Bochdan-Niedenthal. Znalazła się ona, wraz z mężem, w grupie pierwszych kolonistów wysłanych do Montanii. Swój dwuletni pobyt w Ameryce Południowej opisała w książce Ucayali. Raj czy piekło nad Amazonką. Autorce udało się nie tylko dokładnie odtworzyć losy polskich pionierów, ale także oddać stopniową zmianę nastroju, jaka w nich następowała: od entuzjazmu i zachwytu "tropikalnym pięknem" do znużenia oraz rozczarowania.

Odpowiedź na pytanie zawarte w tytule książki Niedenthal (nawiązujące do wspomnianego już wcześniej określenia infierno verde) nie zostaje na jej kartach udzielona w sposób jednoznaczny. „Piekłem”, z całą pewnością, była w oczach autorki „parodia emigracji”, jak określiła działania podjęte przez Kazimierza Warchałowskiego i Syndykat. Oskarżała ona organizatorów o konkretne przewinienia: roztrwonienie pieniędzy, brak zainteresowania sytuacją panującą $\mathrm{w}$ kolonii, wyznaczanie niewłaściwych osób do kierowania przedsięwzięciem, brak profesjonalizmu oraz zły dobór osadników („,przeważnie «lumpenproletarjat» z wykolejonej inteligencji i robotników" 23). Jako cele mające przyświecać polskiemu wychodźstwu, Niedenthal wskazywała chęć pozbycia się z kraju bezrobotnych oraz interesy finansowe poszczególnych osób. Z tego powodu:

Dla twórców takich planów było rzeczą mniejszej wagi, stworzenie komórki kolonizacyjnej, chociażby próbnej tylko, ale opartej na mocnej podstawie, ile „dywersyjne" szukanie terenów w sposób najzupełniej lekkomyślny i udzielenie samemu sobie z góry rozgrzeszenia, za niepowodzenie takiej akcji ${ }^{24}$.

Autorka nie krytykowała jednak samej idei osadnictwa w Montanii wręcz przeciwnie: dostrzegała ona ogromny potencjał tego regionu, który

\footnotetext{
21 M. Jarnecki, Peruwiańska porażka i próba jej naprawy, s. 108-110.

22 K. Warchałowski, Na wodach Amazonki, Warszawa 1938, s. 141.

23 M. Bochdan-Niedenthal, Ucayali. Raj czy piekło nad Amazonka, Warszawa 1935, s. 136.

24 Tamże, s. 135.
} 
pozwalał przypuszczać, że przy lepszej organizacji istniała szansa na stworzenie w Peru znaczącej polskiej kolonii. Co ciekawe, dla części emigrantów warunki życia w amazońskiej dżungli już na początku okazały się znacznie lepsze od tych pozostawionych w ojczyźnie. Tak było w przypadku małżeństwa łódzkich tkaczy:

Dla nich życie w Cumarii graniczyło z ideałem. Dach nad głową, ciepło, łatwość zdobycia niezbędnych środków żywności. Swobodne, beztroskie życie w Montanji wydawało im się rajem po ciężkich trudach życia w Łodzi, gdzie wisiało nad nimi widmo bezrobocia i nędzy na stare lata, a dymy fabryczne i niskie izby robotniczego mieszkania nie pozwalały starym płucom zaczerpnąć pełnego oddechu ${ }^{25}$.

Sposób prezentowania peruwiańskiej rzeczywistości w książce Bochdan-Niedenthal jest więc także podporządkowany kwestii osadniczej. Nie próbuje ona jednak idealizować życia w Montanii, a prezentowane opinie opiera przede wszystkim na własnych doświadczeniach i obserwacjach. Autorka docenia piękno oraz bogactwo południowoamerykańskiej przyrody, wiele miejsca poświęcając również opisom kultury rdzennych mieszkańców tego obszaru. Niebezpieczeństwo, jakie, zdaniem emigrantki, czyhało na Europejczyków nad Ukajali, nie wiązało się z czynnikami przyrodniczo-klimatycznymi. Miało ono polegać na upadku moralnym, o jaki łatwo w świecie, w którym następuje rozluźnienie norm moralnych i obyczajowych.

\section{Podróżnik w świecie pełnym niebezpieczeństw}

Niewątpliwie jednak najpopularniejszą polską książką opisującą wyprawę do Peru, która ukazała się w dwudziestoleciu międzywojennym, była (i do dziś pozostaje) publikacja Arkadego Fiedlera Ryby śpiewaja w Ukajali. Autor zdobył uznanie czytelników już wcześniejszymi tekstami poświęconymi podróży do Brazylii, ale to właśnie utwór z 1935 r. stał się jego pierwszym tak znaczącym sukcesem. Konrad Górski na łamach „Rocznika Literackiego” określił go mianem najpiękniejszej i najlepszej podróżniczej książki sezonu ${ }^{26}$, a rok późnej Polska Akademia Literatury nagrodziła Fiedlera Srebrnym Wawrzynem Akademickim. W 1937 r. podróżnik wydał tekst w nieco innej wersji

25 Tamże, s. 160.

26 K. Górski, Literatura podróżnicza, „Rocznik Literacki za rok 1935”, s. 205. 
(dostosowanej do młodszych czytelników) pod zmienionym tytułem Zdobywamy Amazonkę ${ }^{27}$.

Co ciekawe, mimo że Fiedler przemierza dorzecze Ukajali, a więc dokładnie ten sam region, w którym planowano utworzenie polskiej osady, o wydarzeniu tym w swoim tekście jedynie wzmiankuje (to tu "nieszczęśni polscy koloniści mieli budować swą przyszłość" ${ }^{28}$ ). Po części jest to zapewne związane z porażką projektu i kompromitacją jego autorów, która w momencie ukazania się książki była już faktem. W wydanych po wojnie wspomnieniach Wiek męski - zwycięski podróżnik nazywał wręcz „zbrodniczym błędem" ${ }^{29}$ międzywojenne próby budowania kolonii w Peru. Jednak fakt niemal zupełnego przemilczenia tego tematu może wynikać także z poetyki utworu i autokreacji jej autora. Fiedler, podobnie jak Lepecki we wspomnianej już książce Na Amazonce i we wschodnim Peru, stara się zaprezentować w roli podróżnika-odkrywcy, odwiedzającego niepoznane dotychczas miejsca i penetrującego obszary, do których nie dotarł jeszcze żaden Europejczyk. Podkreślanie faktu wcześniejszej obecności polskich osadników na tym obszarze odbierałoby Montanii aurę niesamowitości, wyjątkowości. Marcin Florian Gawarycki określił autora Kanady pachnacej żywica mianem podróżnika romantycznego, który, zdaniem badacza, „był jednakże egocentrykiem, eksponującym siebie na tle egzotycznej przyrody i - co ważniejsze - egzotycznych kobiet" ${ }^{30}$. Nie może więc dziwić, że pisarz w sposobie prezentowania Peru nie wychodzi poza zestaw powszechnie funkcjonujących wyobrażeń i stereotypów:

Bywają na brzegu rzeki potężne drzewa o konarach tak rozłożystych, że okryłyby chyba pół miasta. Bywają palmy o pióropuszach liści kilkunastometrowych. Powietrze dudni i tętni od krzyku licznego ptactwa. Stada po dwadzieścia arar, krzycząco amarantowych od spodu a lśniąco niebieskich $\mathrm{z}$ wierzchu, to widok o niezatartem wrażeniu. Z gliniastego brzegu zsuwają się do rzeki kajmany, z wody wyskakują ryby-potwory, a las roi się przepychem najcudniejszych owadów ${ }^{31}$.

27 A. Fiedler, Zdobywamy Amazonkę, Warszawa 1937.

28 A. Fiedler, Ryby śpiewaja w Ukajali, Warszawa 1935, s. 138.

29 A. Fiedler, Wiek męski - zwycięski, Warszawa 1976, s. 169. Jak słusznie zauważa Tomasz Kempiński, opinia ta mogła być związana nie tyle z rzeczywistymi poglądami Fiedlera, co z chęcią przypodobania się władzom PRL. Podróżnik przedstawiał się tu bowiem także jako zdecydowany przeciwnik planu kolonizacji Madagaskaru, podczas gdy w swojej książce Jutro na Madagaskar! wypowiadał się na jego temat entuzjastycznie. Zob. T. Kempiński, Egzotyczny świat Arkadego Fiedlera, „Argumenta Historica” 2016, nr 3, s. 47-48.

30 M.F. Gawarycki, W pogoni za wyobrażeniami. Próba interpretacji polskiej literatury podróżniczej poświęconej Ameryce Łacińskiej, Warszawa 2010, s. 91.

31 A. Fiedler, Ryby śpiewaja w Ukajali, s. 93. 
Tak prezentowana dżungla jest $\mathrm{w}$ książce Fiedlera miejscem zachwycającym różnorodnością oraz egzotyką, a jednocześnie to przestrzeń tajemnicza i pełna niebezpieczeństw. Inaczej, niż w propagandowych broszurach działaczy emigracyjnych, na kartach utworu Ryby śpiewaja w Ukajali zagrożenia czyhają na podróżnika niemal wszędzie. Należą do nich choroby tropikalne, trujące rośliny, dzikie zwierzęta, odcięci od cywilizacji rdzenni mieszkańcy czy wreszcie szaleństwo. Według pisarza, „puszcza jest zazdrosna i żarłoczna, do dziś pochłania wiele ofiar nawet wśród tubylców" ${ }^{32}$. Podróż do takiego miejsca wymaga więc brawury oraz odwagi, łączy się z ryzykiem, zarazem dając szansę na zdobycie wyjątkowego doświadczenia. Nie bez przyczyny przywołana zostaje również historia Percy'ego Fawcetta, brytyjskiego podróżnika i eksploratora Ameryki Południowej, który w 1925 roku zaginął w czasie wyprawy w głąb dżungli, a wszelkie próby jego odnalezienia zakończyły się niepowodzeniem. Losy ekspedycji dały Fiedlerowi możliwość pokazania, z jak wielkim ryzykiem wiązała się także jego podróż.

Na sposób prezentowania Peru w książce Arkadego Fidlera wpłynęła wreszcie struktura tekstu. Jest ona charakterystyczna dla większości utworów tego autora, którego technikę pisarską tak charakteryzuje Tomasz Kempiński:

Metoda pracy pisarza była niezwykle prosta - turystyczny wojaż przerywany przystankami co kilka dni, a z każdego z nich nowy felieton - obrazek, niczym fotografia na pamiątkę. Poszczególne obrazki zaś skonstruowane są tak, aby można było budować różne opowieści, nie zawracając sobie głowy chronologią zdarzen ${ }^{33}$.

Kolażowa kompozycja książki, której kolejne części przypominają krótkie felietony czy obrazki, nie daje możliwości budowania zniuansowanych opisów, opartych o pogłębione studia nad poszczególnymi zagadnieniami. Wydaje się zresztą, że nie tego oczekiwali odbiorcy utworów Fiedlera. W swoich tekstach bazował on przede wszystkim na indywidualnych spostrzeżeniach i przeżyciach, nie wykraczając przy tym poza dotychczasowy sposób prezentowania „egzotycznych” krain w europejskiej tradycji podróżopisarskiej. Dzięki temu pisarz zaspokajał czytelniczy "głód" niesamowitości, co było jednym z głównych zadań stawianych przed literaturą podróżniczą na początku dwudziestego wieku.

\footnotetext{
32 Tamże, s. 157.

33 T. Kempiński, Egzotyczny świat Arkadego Fiedlera, s. 47.
} 
Polskie międzywojenne narracje poświęcone Peru w większości podporządkowane były ideologii emigracyjnej, związanej z koncepcją prowadzenia $\mathrm{w}$ tym kraju polityki osadniczej. Teksty napisane przez osoby związane z ideą utworzenia nad Ukajali polskich kolonii mają charakter jednoznacznie propagandowy, a prezentowana $\mathrm{w}$ nich wizja Montanii jest wyidealizowana, częściowo wręcz fałszywa. Na drugim biegunie pisania o peruwiańskich realiach znajdują się publikacje kontestatorów projektu kolonialnego: Adama Jarzyny oraz Marii Bochdan-Niedenthal, w których obraz południowoamerykańskiego kraju wydaje się znacznie bardziej zróżnicowany i niejednoznaczny. Wreszcie, w książce Arkadego Fiedlera Ryby śpiewają w Ukajali, Peru stanowi jedynie tło, na którym autor może zaprezentować siebie $\mathrm{w}$ roli podróżnika-odkrywcy, skupia się więc przede wszystkim na eksponowaniu odmienności i niezwykłości oglądanego świata. Pozostaje tym samym w sferze powszechnie znanych wyobrażeń i egzotyzmów. Analiza tekstów poświęconych Peru, które powstały w latach 1918-1939, pozwala zauważyć, że dyskurs dominujący w ówczesnych relacjach z podróży bardzo często podporządkowany był realizacji konkretnych celów, związanych zarówno z polityką, poetyką utworu, jak i indywidualnymi potrzebami autorów.

\section{Bibliografia}

Bochdan-Niedenthal Maria (1935), Ucayali. Raj czy piekło nad Amazonka, Warszawa: Dom Książki Polskiej.

Fiedler Arkady (1935), Ryby śpiewaja w Ukajali, Warszawa: Towarzystwo Wydawnicze „Rój”.

Fiedler Arkady (1976), Wiek męski - zwycięski, Warszawa: Iskry.

Fiedler Arkady (1937), Zdobywamy Amazonkę, Warszawa: Towarzystwo Wydawnicze „Rój”.

Gawarycki Marcin Florian (2010), W pogoni za wyobrażeniami. Próba interpretacji polskiej literatury podróżniczej poświęconej Ameryce Łacińskiej, Warszawa: Wydawnictwa Uniwersytetu Warszawskiego.

Gieysztor Michał (1933), Peru, Warszawa: Towarzystwo Wydawnicze „Rój”.

Górski Konrad (1936), Literatura podróżnicza, "Rocznik Literacki za rok 1935”, s. 202-213.

Jarnecki Michał (2014), Peruwiańska porażka i próba jej naprawy. Wokót polskich międzywojennych koncepcji emigracyjnych $i$ kolonialnych, „Sprawy Narodowościowe. Seria Nowa", nr 44, s. 102-132.

Jarzyna Adam (1931), Peru. Widoki dla osadnictwa rolnego na terenach polskich koncesyj, Lwów-Warszawa: Księgarnia Polska B. Połoniecki. 
Kania Marta (2016), Żyć można w Montanji całe lata - o kolonizacji polskiej w Peru, w: Pani Anna w Kanadzie: ksiega pamiątkowa dedykowana Pani Profesor Annie Reczyńskiej, red. M. Gabryś, M. Paluszkiewicz-Misiaczek, Kraków: Księgarnia Akademicka, s. $17-37$.

Kempiński Tomasz (2016), Egzotyczny świat Arkadego Fiedlera, „Argumenta Historica”, nr 3, s. 42-59.

Kurowski Karol (2019), Relacje polsko-peruwiańskie w latach 1923-1945. Działalność Polaków w Peru, w: Polacy w dziejach Peru, red. S. Rakowicz, Torun: Wydawnictwo Naukowe Uniwersytetu Mikołaja Kopernika, s. 143-153.

Lepecki Mieczysław Bohdan (1930), Opis polskich terenów kolonialnych w Peru, Warszawa: Naukowy Instytut Emigracyjny.

Lepecki Mieczysław Bohdan (1931), Na Amazonce i we wschodnim Peru, Lwów-Warszawa: Książnica Atlas.

Mazurek Jerzy (2013), Piórem i czynem. Kazimierz Warchałowski (1872-1943) - pionier osadnictwa polskiego w Brazylii i Peru, Warszawa: Muzeum Historii Polskiego Ruchu Ludowego, Instytut Studiów Iberyjskich i Iberoamerykańskich UW.

Oxiński Tomasz (1932), Peru, Warszawa-Poznań: Wydawnictwo Wiesława Tomaszewskiego.

Pankiewicz Michał (1929), Ustrój społeczny Montanji peruwiańskiej a praktyczne wskazania dla polskiego osadnictwa, Warszawa: Naukowy Instytut Emigracyjny.

Tragedia emigrantów polskich VII (1932), „Dziennik Bydgoski”, nr 19, s. 4.

Warchałowski Kazimierz (1930), Peru. Warunki gospodarcze Montanji Peruwiańskiej, Warszawa: Kolonja Polska.

Warchałowski Kazimierz (1938), Na wodach Amazonki, Warszawa: Wydawnictwo Ligi Morskiej i Kolonialnej.

\title{
"We Can Create a Really Beautiful and Rich Polish Colony Here": Polish Descriptions of Peru in the Interwar Period (1918-1939)
}

\begin{abstract}
The article shows how Polish authors described Peru in the interwar period (1918-1939) and what influenced their writing. Most of the texts on Peru were written in the years 1928-1933 and were related to the idea of creating Polish colonies for emigrants in this country. The books of Kazimierz Warchałowski, Michał Pankiewicz and Mieczysław Lepecki were propaganda works. Their goal was to encourage Polish farmers to leave, which is why they depicted Peru in an idealized way. There are also texts criticizing the plan of establishing colonies, in which life in Peru is shown more realistically. The exception is Arkady Fiedler's travel book, in which the author tries to fashion himself as an exceptional traveler-explorer. For this reason, he describes Peru as an unknown and dangerous place.
\end{abstract}

Keywords: travel writing, the interwar period, Polish travelers, Polish colonies in Peru, propaganda 